\title{
PENGARUH LEMBAR KERJA MAHASISWA DALAM MODEL PEMBELAJARAN DISCOVERY LEARNING TERHADAP KEMAMPUAN PENALARAN DAN KOMUNIKASI MATEMATIS MAHASISWA FMIPA UNIMED
}

\author{
Glory Indira D. Purba, Edy Surya, Martua Manullang, Asmin
}

Surel: glous_poerba@yahoo.com

\begin{abstract}
ABSTRAK
Salah satu kegiatan awal dalam meningkatkan pembelajaran adalah merancang perangkat pembelajaran yang mengacu pada suatu model agar memudahkan belajar. Perancangan pembelajaran dapat dijadikan titik awal upaya perbaikan kualitas pembelajaran. Ini berarti bahwa perbaikan kualitas pembelajaran haruslah diawali dari perbaikan kualitas desain pembelajaran, dan merancang pembelajaran dengan pendekatan sistem. Hendaknya dalam pembuatannya dipadupadankan dengan metode dan juga model yang sesuai dengan kebutuhan peserta didik agar pembelajaran lebih bermakna (meaning full). Penelitian ini adalah penelitian eksperimen yang dilakukan pada mahasiswa program studi pendidikan dengan tujuan: (1)mengetahui perbedaan kemampuan penalaran dan komunikasi matematis mahasiswa yang diajar dengan menggunakan LKM dalam model discovery learning dan metode ceramah; (2) menelaah proses jawaban mahasisa yang diajar dengan menggunakan LKM dalam model discovery learningdan metode ceramah; (3) menghasilkan perangkat pembelajaran matematika berupa LKM berbasis discovery learning yang layak digunakan untuk meningkatkan kemampuan penalaran dan komunikasi matematis mahasiswa matematika.
\end{abstract}

Kata kunci: Discovery Learning, Metode Ceramah, LKM

\section{PENDAHULUAN}

Salah satu kegiatan awal dalam meningkatkan pembelajaran adalah merancang perangkat pembelajaran yang mengacu pada suatu model agar memudahkan belajar. Perancangan pembelajaran dapat dijadikan titik awal upaya perbaikan kualitas pembelajaran. Iniberarti bahwa perbaikan kualitas pembelajaran haruslah diawali dari perbaikan kualitas desain pembelajaran, dan merancang pembelajaran dengan pendekatan sistem.

Agar menjadi perangkat pembelajaran yang menarik untuk dipakai, hendaknya dalam pembuatannya dipadupadankan dengan metodedan juga model yang sesuai dengan kebutuhan peserta didik agar pembelajaran lebih bermakna (meaningfull). Dalam pembelajaran di kampus, dosen hendaknya selalu berinovasi dalam menciptakan pembelajaran yang inovatif melalui perancangan perangkat pembelajaran sebagai media yang dapat digunakan dalam proses pembelajaran. Upaya perancangan perangkat pembelajaran sebagai media dalam proses pembelajaran penting untuk dilakukan guna mewujudkan pembelajaran yang efektif dan efisien. Sehingga kompetensi yang harus dicapai oleh mahasiswa dapat dikuasai. Salah satunya adalah dengan menggunakan Lembar Kerja Mahasiswa (LKM). Mahasiswa diharapkan mampu menguasai konsep melalui panduan pada lembar 

kerja dan bekerjasama dalam kelompoknya.

\begin{tabular}{lcr}
\multicolumn{2}{c}{ Disamping } & perangkat \\
pembelajaran, & faktor & yang \\
mempengaruhi & rendahnya & mutu \\
pendidikan, diantaranya & adalah
\end{tabular}
penalaran dan komunikasi matematis mahasiswa. Materi matematika, penalaran dan komunikasi matematis merupakan hal yang tidak dapat dipisahkan, yaitu materi matematika dipahami melalui penalaran dan penalaran dipahami dan dilatihkan melalui belajar materi matematika sampai mampu mengkomunikasikannya. Uraian ini menuntut mahasiswa untuk dapat bernalar dan berkomunikasi dengan baik guna mengembangkan pola pikirnya. Namun, dilapangan menunjukkan kemampuan penalaran dan komunikasi matematis mahasiswa masih rendah. Hal ini dapat dilihat dengan rendahnya hasil yang dicapai mahasiswa jika diberikan soal-soal yang berbeda dengan contoh yang ada. Mahasiswa yang mengetahui konsep-konsep dasar tidak mampu menghubungkan antara kondisi yang memiliki keterkaitan untuk menyelesaikan persoalan berbeda.

Rendahnya kemampuan penalaran dan komunikasi matematis mahasiswa dipengaruhi oleh beberapa faktor. Salah satu faktornya adalah proses pembelajaran. Dalam proses pembelajaran, model pembelajaran memainkan peranan penting dan merupakan salah satu penunjang utama seorang dosen dalam mengajar. Model yang dipakai oleh dosen akan berpengaruh pula pada cara belajar mahasiswa, untuk itu perlu model yang mendorong mahasiswa aktif sehingga dapat memahami materi matematika yang diajarkan. Didalam pembelajaran discovery learning, peserta didik didorong untuk menemukan sendiri dan mentransformasikan informasi kompleks, mengecek informasi baru dengan yang sudah ada dalam ingatannya, dan melakukan pengembangan menjadi informasi atau kemampuan yang sesuai dengan lingkungan dan zaman tempat dan waktu ia hidup. Image model discovery learning adalah teori belajar yang didefinisikan sebagai proses pembelajaran yang terjadi bila pelajar tidak disajikan dengan pelajaran dalam bentuk finalnya, tetapi diharapkan mengorganisasi sendiri.

Berbeda dengan model pembelajaran ceramah, peserta didik hanya menerima materi dari dosen tanpa dipaksa untuk berpikir lebih jauh dan mendalam tentang materi yang sedang disampaikan. Menurut Sanjaya (2010: 147), "Pembelajaran ceramah merupakan model yang cara menyajikan pelajaran melalui penuturan secara lisan atau penjelasan langsung kepada kelompok siswa." Sedangkan Djamarah (2006: 97) menyatakan "Modelpembelajaran ceramah adalah model yang boleh dikatakan bersifat tradisional, karena sejak dulu model ini telah dipergunakan sebagai alat komunikasi lisan antara guru dengan peserta didik dalam proses belajar 
Glory Indira D. Purba, Edy Surya, Martua Manullang ...

mengajar." Untuk itu salah satu solusi yang ditawarkan dalam memperbaiki proses pembelajaran matematika khususnya untuk meningkatkan kemampuan penalaran dan komunikasi matematis mahasiswa yaitu dengan menggunakan lembar kerja mahasiswa berbasis discovery learning dan model ceramah.

\section{METODE PENELITIAN}

Jenis penelitian yang digunakan adalah penelitian eksperimen semu, yaitu penelitian yang dimaksudkan untuk mengetahui ada tidaknya akibat dari sesuatu yang dikenakan pada subjek yaitu siswa, dengan kata lain penelitian eksperimen adalah mencoba meneliti ada tidaknya hubungan sebab akibat. Pelaksanaannya dengan melibatkan dua kelompok eksperimen, yaitu kelas yang diajarkan dengan menggunakan model pembelajaran Discovery Learning disebut sebagai kelas eksperimen A dan kelas yangdiajarkan dengan menggunakan model pembelajaran ceramah disebut sebagai kelas eksperimen B.

Desain penelitian ini menggunakan Pretest-Postest Control Group Design. Sampel yang diambil dalam penelitian ini dikelompokkan menjadi dua kelompok eksperimen yaitu kelompok pertama sebagai kelas eksperimen A dan kelompok kedua sebagai kelas eksperimen B. Kedua kelas sampel tersebut terlebih dahulu diberikan pretest untuk mengetahui kemampuan atau pemahaman mahasiswa mengenai materi yang akan diajarkan sebelum dilakukan pembelajaran serta untuk memperoleh sampel yang homogen.

\section{HASIL PENELITIAN DAN PEMBAHASAN}

Penemuan (Discovery) adalah suatu metode/strategi yang berpusat pada mahasiswa dimana kelompokkelompok mahasiswa di hadapkan pada suatu persoalan untuk mencari jawaban atas pertanyaan-pertanyaan dalam suatu prosedur dan struktur kelompok yang digariskan secara jelas. Metode penemuan (discovery) oleh Suryosubroto (2009) diartikan sebagai prosedur mengajar yang mementingkan pengajaran, perseorangan, manipulasi obyek dan percobaan, sebelum sampai kepada generalisasi. Sehingga metode penemuan (Discovery) merupakan komponen dari praktek pendidikan yang meliputi metode mengajar yang memajukan cara belajar aktif, berorientasi pada proses, mengarahkan sendiri, mencari sendiri, dan reflektif. Menurut Hanafiah (2009) metode penemuan (discovery) merupakan suatu rangkaian kegiatan pembelajaran yang melibatkan seluruh kemampuan mahasiswa secara maksimal untuk mencari dan menyelidiki secara sistematis, kritis, dan logis sehingga mahasiswa dapat menemukan sendiri pengetahuan, sikap, dan keterampilan sebagai wujud adanya perubahan tingkah laku.

Dari beberapa pendapat di atas maka dapat disimpulkan bahwa 
metode penemuan (Discovery) adalah suatu metode di mana dalam proses belajar mengajar guru memperkenankan mahasiswanya untuk menemukan sendiri, mengarahkan sendiri, mencari sendiri, menyelidiki sendiri konsep dan prisip dari pengetahuan, sikap dan keterampilan sehingga menimbulkan perubahan tingkah laku mahasiswa.

Menurut Elfira (2013:32) Adapun langkah-langkah dalam discovery learning sebagai berikut :

- Stimulasi (stimulasi/pemberian rangsangan)

Pertama-tama pada tahap ini pelajar dihadapkan pada sesuatu yang menimbulkan kebingungannya, kemudian dilanjutkan untuk tidak memberi generalisasi, agar timbul keinginan untuk menyelidiki sendiri. Stimulasi pada tahap ini berfungsi untuk menyediakan kondisi interaksi belajar yang dapat mengembangkan dan membantu peserta didik dalam mengeksplorasi bahan.

- Problem

Statement

(pernyataan/identifikasi masalah)

Dalam tahap ini guru memberi kesempatan kepada peserta didik untuk mengidentifikasi sebanyak mungkin agenda-agenda masalah yang relevan dengan bahan pelajaran, kemudian salah satunya dipilih dan dirumuskan dalam bentuk hipotesis.

- Data collection (pengumpulan data)
Ketika eksplorasi berlangsung, guru juga memberi kesempatan kepada para peserta didik untuk mengumpulkan informasi sebanyak-banyaknya yang relevan untuk membuktikan benar atau tidaknya hipotesis. Pada tahap ini berfungsi untuk menjawab pertanyaan atau membuktikan benar tidaknya hipotesis.

- Data processing (pengolahan data)

Pengolahan data merupakan kegiatan pengolahan data dan informasi yang telah diperoleh para peserta didik baik selanjutnya ditafsirkan, dan semuanya diolah serta ditafsirkan pada tingkat kepercayaan tertentu. Data processing berfungsi sebagai pembentukan konsep dan generalisasi.

- Verification (pembuktian)

Pada tahap ini, peserta didik melakukan pemeriksaan secara cermat untuk membuktikan benar atau tidaknya hipotesis yang ditetapkan dengan temuan alternatif, dihubungkan dengan hasil data processing.

- Generalization (menarik kesimpulan/generalisasi)

Tahap generalisasi/menarik kesimpulan yang dapat dijadikan prinsip umum dan berlaku untuk semua kejadian atau masalah yang sama, dengan memperhatikan hasil verifikasi, maka dirumuskan prinsip-prinsip yang mendasari generalisasi. 
Glory Indira D. Purba, Edy Surya, Martua Manullang ...

Dari uraian diatas dapat disimpulkan bahwa model discovery learning adalah pembelajaran yang menekankan kepada pentingnya pemahaman struktur atau ide-ide penting terhadap suatu disiplin ilmu, melalui keterlibatan siswa secara aktif untuk belajar.

Menurut Sanjaya (2010: 147), "Metode ceramah merupakan metode yang cara menyajikan pelajaran melalui penuturan secara lisan atau penjelasan langsung kepada kelompok siswa." Sedangkan Djamarah (2006: 97) menyatakan "Metode ceramah adalah metode yang boleh dikatakan metode tradisional, karena sejak dulu metode ini telah dipergunakan sebagai alat komunikasi lisan antara guru dengan peserta didik dalam proses belajar mengajar."

Menurut Sanjaya (2010: 149)

ada beberapa hal yang harus dilakukan, baik pada tahap persiapan maupun pada tahap pelaksanaan, sebagai berikut:

- Tahap Persiapan

a. Merumuskan tujuan yang ingin dicapai.

b. Menentukan pokok-pokok materi yang akan diceramahkan.

- Tahap Pelaksanaan

a. Langkah pembukaan yaitu Guru menyampaikan tujuan yang ingin dicapai. Apersepsi, guru bertanya atau memberikan uraian singkat untuk mengarahkan perhatian anak didik kepada materi yang akan diajarkan. b. Langkah penyajian

Langkah penyajian adalah tahap penyampaian materi pembelajaran dengan cara bertutur. Agar ceramah kita berkualitas sebagai metode pembelajaran, maka guru harus menjaga perhatian siswa agar tetap terarah pada materi pembelajaran yang sedang disampaikan.

c. Langkah mengakhiri atau menutup ceramah

Terdapat dua macam penalaran, yaitu penalaran deduktif dan penalaran induktif. Penalaran deduktif merupakan cara berpikir dimana dari pernyataan umum ditarik kesimpulan yang bersifat khusus, penarikan kesimpulan menggunakan silogisme (konstruksi penalaran). Silogisme terdiri atas kalimatkalimat pernyataan yang dalam logika/penalaran disebut proposisi. Proposisi-proposisiyang menjadi dasar penyimpulan disebut premis, sedangkan kesimpulannya disebut konklusi. Silogisme berfungsi sebagai proses pembuktian benarsalahnya suatu pendapat, tesis atau hipotesis tentang masalah tertentu. Deduksi berpangkal dari suatu pendapat umum berupa teori, hukum atau kaedah dalam menyusun suatu penjelasan tentang suatu kejadian khusus atau dalam menarik kesimpulan.

Ketika menemukan atau membuktikan suatu prinsip, dikembangkan pola pikir induktif dan deduktif. Mahasiswa dibiasakan 
melihat ciri-ciri beberapa kasus, melihat pola danmembuat dugaan tentang hubungan yang ada diantara kasus-kasus itu, serta selanjutnya menyatakan hubungan yang berlaku umum (generalisasi, penalaran induktif). Disamping itu mahasiswa juga perlu dibiasakan menerima terlebih dahulusuatu hubungan yang jelas kebenarannya, selanjutnya menggunakan hubungan itu untuk menemukan hubungan-hubungan lainnya (penalaran deduktif). Jadi baik penalaran deduktif maupun induktif, keduanya amat penting dalam pembelajaran matematika. Kemampuan penalaran matematis mahasiswa dalam pembelajaran perlu dikembangkan. Adapun indikator yang menunjukkan adanya penalaran dalam matematika antara lain: (1) menyajikan pernyataan matematika secara lisan, tertulis, gambar dandiagram, (2) mengajukan dugaan, (3) melakukan manipulasi matematika, (4) menarik kesimpulan, menyusun bukti, memberikan alasan atau bukti terhadap beberapa solusi, (5) menarik kesimpulan dari pernyataan, (6) memeriksa kesahihan suatu argumen, (7) menentukan pola atau sifat dari gejala matematis untuk membuat generalisasi.

Jadi kemampuan penalaran matematis yang dimaksud adalah kemampuan berpikir menurut alur kerangka berpikir tertentu berdasarkan konsepatau pemahaman yang telah didapat sebelumnya. Kemudian konsep atau pemahaman tersebut saling berhubungan satu sama lain dan diterapkan dalam permasalahan baru sehingga didapatkan keputusan baru yang logis dan dapat dipertanggungjawabkan atau dibuktikan kebenarannya.

Adapun tujuan dari kemampuan penalaran matematik yang diungkapkan Marina (2013 : 13) adalah "Siswa mampu menggunakan penalaran pada pola dan sifat, melakukan manipulasi matematika dalam membuat generalisasi, menyusun bukti, atau menjelaskan gagasan dan pernyataan matematika. Selain itu juga diharapkan agar siswa dapat menggunakan matematika sebagai cara bernalar (berpikir logis, kritis, sistematis, dan objektif)". Dari pendapat diatas, dapat ditarik kesimpulan bahwa untuk dapat memecahkan suatu masalah, para siswa perlu memiliki kemampuan penalaran yang dapat diperoleh melalui pembelajaran matematika.

Menurut Sumiati danAsra (2007) komunikasi merupakan bagian yang hakiki dari kehidupan manusia. Demikian pula dalam kehidupan di sekolah. Komunikasi memegang peranan penting dalam matematika. Setiap orang yang berkepentingan dengan matematika akan memerlukan komunikasi dalam perbendaharaan informasi yang lebih banyak. NCTM (2000) menyatakan bahwa komunikasi merupakan bagian yang esensial dari matematika dan pendidikan matematika. Tanpa komunikasi yang baik, maka perkembangan matematika akan terhambat. Fakta ini menjadi 
Glory Indira D. Purba, Edy Surya, Martua Manullang ...

tantangan bagi masyarakat pendidikan matematika dalam usaha mereka untuk mengkomunikasikan apa yang sudah mereka evaluasi, percaya, dan mengenal siswa sedemikian hingga para siswa menjadi terdidik secara metematik. Komunikasi menjadi sesuatu yang utama dalam mengajar, menilai, dan dalam pembelajaran matematika.

Adapun kemampuan yang tergolong dalam komunikasi matematika menurut Utari-Sumarmo (2005) diantaranya adalah:

a. Menyatakan suatu situasi, gambar, diagram, atau benda nyata ke dalam bahasa, simbol, ide, atau model matematika

b. Menjelaskan ide, situasi, dan relasi matematika secara lisan atau tulisan

c. Mendengarkan, berdiskusi, dan menulis tentang matematika

d. Membaca dengan pemahaman suatu representasi matematika tertulis

e. Membuat konjektur, merumuskan definisi, dan generalisasi

f. Mengungkapkan kembali suatu uraian atau paragraf matematika dalam bahasa sendiri.

Komunikasi dapat diklasifikasikan dalam berbagai cara. Kita dapat membagi komunikasi ke dalam:

a. Komunikasi verbal (komunikasi dengan menggunakan kata-kata) Komunikasi verbal dibagi 2 yaitu komunikasi verbal lisan dan komunikasi verbal tulisan. b. Komunikasi nonverbal (komunikasi tanpa menggunakan kata-kata atau pesan-pesan yang dinyatakan lewat sarana yang bukan sarana linguistik).

National Cuoncil Teacher of Mathematic (Ansari: 2009 ) mengemukakan bahwa matematika sebagai alat komunikasi (mathematics as comunication) merupakan pengembangan bahasa dan simbol untuk mengkomunikasikan ide matematik sehingga siswa dapat:

Mengungkapkan dan menjelaskan pemikiran mereka tentang ide matematik dan hubungannya, (2) Merumuskan defenisi matematik dan membuat generalisasi yang diperoleh melalui investigasi (penemuan), (3) Mengungkapkan ide matematik secara lisan dan tulisan, Membaca wacana matematika dengan pemahaman, (5) Menjelaskan dan mengajukan pertanyaan terhadap matematika yang dipelajari, dan (6) Menghargai keindahan dan kekuatan notasi matematik serta peranannya dalam mengembangkan ide/gagasan matematik.

2009) terdapat lima aspek
komunikasi yaitu: representasi, mendengarkan (listening), membaca (reading), diskusi, dan menulis.

a. Representasi adalah (1) bentuk baru sebagai hasil transisi dari suatu Masalah,atau ide, (2) translasi suatu diagram atau model fisik kedalam simbol atau kata-kata. 
b. Mendengarkan merupakan aspek penting dalam suatu diskusi. Baroody (Ansari 2009) mengatakan mendengar secara hati-hati terhadap pertanyaan teman dalam suatu grup juga dapat membantu siswa mengkonstruksi lebih lengkap pengetahuan matematika dan mengatur strategi jawaban yang lebih efektif.

c. Membaca adalah aktivitas memahami suatu teks secara aktif untuk mencari jawaban atas pertanyaan-pertanyaan yang telah disusun. Guthrie (Ansari 2009) mengembangkan lima langkah untuk membantu pembaca agar dapat mencari informasi yang diperlukan dalam suatu teks atau dokumen kelima langkah tersebut adalah: (1). Merumuskan tujuan bahwa bahwa penelusuran suatu teks untuk menemukan sesuatu,(2) Menentukan bagaimana informasi yang terdapat dalam suatu dokumen dapat ditemukan secara mudah, (3) Menyarikan informasi yang dikemukakan didalam teks,

Mengintegrasikan dengan apa yang telah diketahui sebelumnya, (5) Jika langkah ini tidak memuaskan tujuan maka kembali ke langkah (2).

d. Diskusi merupakan sarana untuk mengungkapkan dan merefleksikan pikiran siswa. Baroody (1993) mengemukakan beberapa kelebihan dari diskusi kelas yaitu: (1) Dapat mempercepat pemahaman materi pembelajaran dan kemahiran menggunakan strategi, (2) Membantu siswa mengkonstruksi pemahaman matematik, menginformasikan bahwa para ahli matematika biasanya tidak memecahkan masalah secara sendiri-sendiri, tetapi membangun bersama pakar lain dalam satu tim, dan (3) Membantu siswa menganalisis dan memecahkan masalah secara bijaksana.

e. Menulis adalah suatu kegiatan yang dilakukan dengan sadar untuk mengungkapkan dan merefleksikan pikiran. Menulis bagi siswa memiliki kegunaan dan keuntungan yaitu: (1) Agar siswa dapat merangkum pelajaran dengan bahasa meraka sendiri, (2) Agar siswa dapat membuat pertanyaan sendiri yang berguna untuk merefleksikan pada fokus yang tidak mereka pahami, (3) Agar siswa dapat menjelaskan prosedur penyelesaian dan bagaimana menghindari suatu kesalahan, (4) Agar siswa dapat menjelaskan istilah yang muncul dalam bahasa mereka sendiri dan (5) Agar siswa dapat menulis laporan yang dapat membantu pemahaman siswa.

\section{HASIL PENELITIAN DAN PEMBAHASAN \\ Penelitian ini merupakan suatu studi eksperimen dengan desain penelitian pre-test-post-test}


Glory Indira D. Purba, Edy Surya, Martua Manullang ...

control group design. Populasi dalam penelitian ini adalah seluruh mahasiswa FMIPA semester 1 (satu) dengan mengambil sampel dua kelas (kelas eksperimen A dan kelas eksperimen B) melalui teknik random sampling. Data diperoleh melalui tes kemampuan penalaran matematik, dan tes kemampuan komunikasi matematik. Data dianalisis dengan uji ANAVA duajalur. Sebelum digunakan uji ANAVA dua jalur terlebih dahulu dilakukan uji homogenitas dalam penelitian dan normalitas dalam penelitian ini dengan taraf signifikan $5 \%$. Hasil analisis data menunjukkan bahwa rata-rata tes kemampuan pemecahan masalah kelas eksperimen adalah 34,64 dan kelas kontrol adalah 22,71 dengan nilai sig $=0$, dengan $0<\alpha=0,05$ maka terdapat perbedaan kemampuan penalaran mahasiswa yang diajarkan dengan bantuan LKM (Lembar Kegiatan Mahasiswa) pada model pembelajaran Discovery Learning dengan model pembelajaran Ceramah, rata-rata tes kemampuan komunikasi eksperimen dan kontrol adalah 13,3 dan 7,58 dengan p-value (2-tailed) adalah 0 , dengan $0<\alpha=$ 0,05 maka terdapat perbedaan kemampuan komunikasi matematik mahasiswa yang diajarkan dengan Discovery Learning menggunakan LKM (Lembar Kegiatan Mahasiswa) dengan Pembelajaran Ceramah.
Pengolahan dan analisis data tes awal dan akhir bertujuan untuk mengetahui kemampuan penalaran mahasiswa sebelum dan sesudah memperoleh model discovery learning di kelas eksperimen A dan kemampuan penalaran mahasiswa sebelum dan sesudah memperoleh pembelajaran ceramah di kelas eksperimen B. Berdasarkan data diperoleh skor hasil pengolahan data terhadap skor tes kemampuan penalaran dikumpulkan dan dianalisis untuk mengetahui perbedaan kemampuan penalaran matematik siswa yang diajarkan dengan model discovery learning dan model ceramah. Data ini diperoleh dari hasil kemampuan penalaran matematik baik dari kelas eksperimen A maupun kelas eksperimen B.

Pada Tabel di atas dapat dilihat bahwa rerata pretes mahasiswa yang mendapat pembelajaran Discovery Learning (DL) dan Pembelajaran Ceramah (PC) begitu juga dapat dilihat bahwa rerata postes mahasiswa yang mendapat model pembelajaran Discovery Learning dan Pembelajaran Ceramah. Dari data yang dimuat dapat dibuat diagram yang menunjukkan perbandingan kemampuan penalaran matematik siswa antara Pembelajaran Discovery Learning dan Pembelajaran Ceramah, sebagaimana disajikan pada Tabel berikut: 
Tabel Deskripsi Data Kemampuan Penalaran Matematik Kedua Kelompok Pembelajaran

\begin{tabular}{|l|c|c|c|c|}
\hline \multirow{4}{*}{ Statistik } & \multicolumn{4}{|c|}{ Pembelajaran } \\
\cline { 2 - 5 } & \multicolumn{2}{|c|}{$\begin{array}{c}\text { Discovery Learning } \\
\text { DL }\end{array}$} & \multicolumn{2}{c|}{$\begin{array}{c}\text { Pembelajaran Ceramah } \\
\text { (PC) }\end{array}$} \\
\cline { 2 - 5 } & Pretes & Postes & Pretes & Postes \\
\hline N & $\mathbf{6 4}$ & $\mathbf{6 4}$ & $\mathbf{6 6}$ & $\mathbf{6 6}$ \\
\hline Rata-rata & $\mathbf{1 6 , 3 8}$ & $\mathbf{3 4 , 6 4}$ & $\mathbf{1 3 , 3 9}$ & $\mathbf{2 2 , 7 1}$ \\
\hline $\begin{array}{l}\text { Simpangan } \\
\text { baku }\end{array}$ & $\mathbf{6 , 8 7 9}$ & $\mathbf{9 , 5 3 9}$ & $\mathbf{6 , 0 8 4}$ & $\mathbf{8 , 1 5 0}$ \\
\hline
\end{tabular}

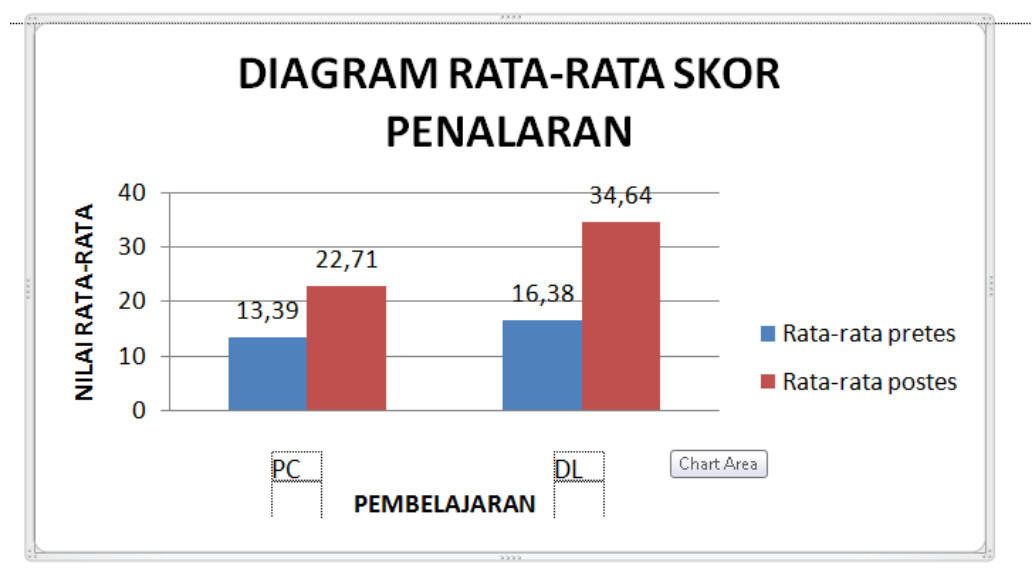

Gambar Rata-rata skor kemampuan Penalaran

Dari data yang dimuat pada Tabel dan diagram pada Gambar di atas diperoleh fakta bahwa sebelum pembelajaran, rata-rata kemampuan penalaran matematik mahasiswa yang mendapat model pembelajaran DL menggunakan LKM hanya sebesar 16,38, sedangkan nilai ratarata kemampuan penalaran matematik mahasiswa yang mendapat model pembelajaran ceramah (PC) sebesar 13,39. Setelah pembelajaran, terjadi perbedaan ratarata kemampuan penalaran matematik kedua kelompok mahasiswa tersebut. Mahasiswa yang mendapat model DL memperoleh rata-rata kemampuan penalaran matematik sebesar 34,64 sementara mahasiswa yang mendapat pembelajaran ceramah memperoleh rata-rata kemampuan penalaran matematik sebesar 22,71.

Pengolahan dan analisis data tes awal dan akhir bertujuan untuk mengetahui kemampuan komunikasi matematis siswa sebelum dan sesudah memperoleh pembelajaran Discovery Learning (DL) di kelas eksperimen A dan kemampuan komunikasi matematis siswa sebelum dan sesudah memperoleh pembelajaran Ceramah (PC) di kelas eksperimen B. Berdasarkan data diperoleh skor hasil pengolahan data terhadap skor tes kemampuan komunikasi matematik dikumpulkan dan dianalisis untuk mengetahui perbedaan kemampuan komunikasi matematik siswa yang diajarkan 
Glory Indira D. Purba, Edy Surya, Martua Manullang ...

dengan DL menggunakan LKM dan PC. Data ini diperoleh dari hasil kemampuan komunikasi matematik baik dari kelas eksperimen A

maupun kelas eksperimen B.

Tabel Deskripsi Data Kemampuan Komunikasi Matematik Mahasiswa Kedua Kelompok Pembelajaran

\begin{tabular}{|l|c|c|c|c|}
\hline \multirow{2}{*}{ Statistik } & \multicolumn{4}{|c|}{ Pembelajaran } \\
\cline { 2 - 5 } & \multicolumn{3}{|c|}{ DL } & \multicolumn{2}{c|}{ PC } \\
\cline { 2 - 5 } \multicolumn{1}{|c|}{ Pretes } & $\mathbf{6 4}$ & $\mathbf{6 4}$ & $\mathbf{6 6}$ & $\mathbf{6 6}$ \\
\hline Rata-rata & $\mathbf{4 , 2 3}$ & $\mathbf{1 3 , 3 8}$ & $\mathbf{4 , 4 4}$ & $\mathbf{7 , 5 8}$ \\
\hline $\begin{array}{l}\text { Simpangan } \\
\text { baku }\end{array}$ & $\mathbf{2 , 4 7 4}$ & $\mathbf{3 , 2 4 4}$ & $\mathbf{2 , 4 1 2}$ & $\mathbf{2 , 4 8 7}$ \\
\hline
\end{tabular}

Secara umum diagram batang yang mendeskripsikan skor rerata kemampuan komunikasi matematik sebagaimana disajikan pada tabel dapat dilihat pada gambar berikut:

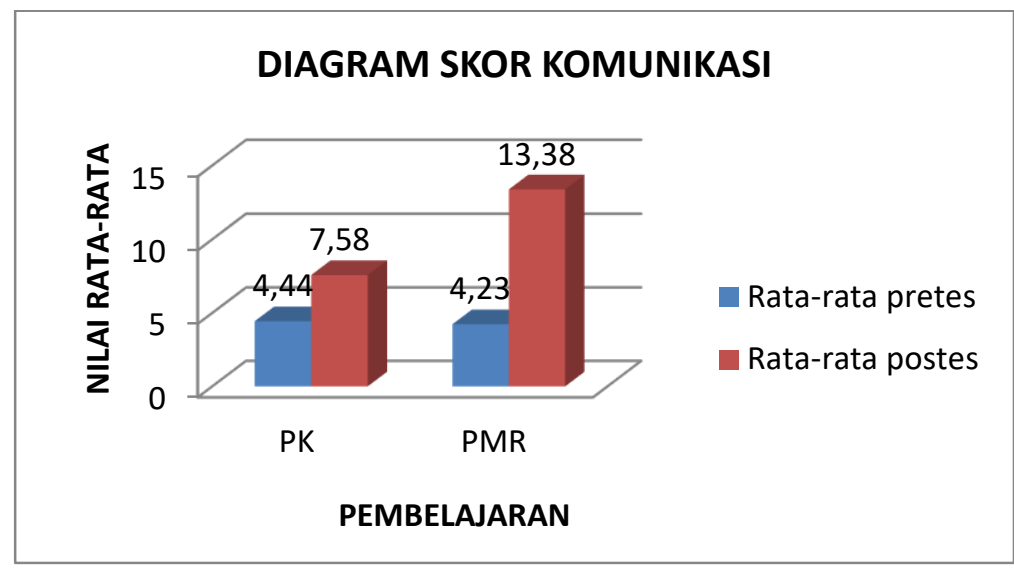

Gambar Rata-rata skor kemampuan komunikasi matematik

Pada Tabel dan Gambar di atas tampak bahwa sebelum pembelajaran, rata-rata kemampuan komunikasi matematik mahasiswa yang mendapat model pembelajaran DL hanya sebesar 4,23, sedangkan nilai rata-rata kemampuan komunikasi matematik mahasiswa yang mendapat pembelajaran ceramah sebesar 4,44. Setelah pembelajaran, terjadi perbedaan rata- rata kemampuan komunikasi matematik kedua kelompok mahasiswa tersebut. Mahasiswa yang mendapat model pembelajaran DL memperoleh rata-rata kemampuan komunikasi sebesar 13,38 sementara mahasiswa yang mendapat pembelajaran ceramah memperoleh rata-rata kemampuan komunikasi matematik sebesar 7,58. 


\section{Pembahasan}

Berdasarkan hasil analisis data terhadap rata-rata skor pretes yang dilakukan pada kelompok mahasiswa yang memperoleh pembelajaran melalui model pembelajaran Discovery Learning menggunakan LKM dengan rata-rata sebesar 16,38 dan pada kelompok mahasiswa yang memperoleh pembelajaran hanya melalui model pembelajaran ceramah dengan ratarata sebesar 13,39. Dari hasil pengujian data rerata skor pretes terhadap kedua kelompok dapat disimpulkan bahwa kedua kelompok memiliki kemampuan awal yang sama atau tidak terdapat perbedaan yang signifikan.Setelah adanya pembelajaran Discovery Learning untuk kelas eksperimen A dan pembelajaran ceramah untuk kelas eksperimen B, maka diperoleh skor postes untuk kemampuan pemecahan masalah matematik pada kedua kelas. Rerata skor postes kemampuan pemecahan masalah matematik siswa kelas eksperimen adalah 34,64 dan simpangan baku 9,539 demikian pula rerata skor kemampuan pemecahan masalah matematis siswa pada kelas kontrol adalah 22,71 dan simpangan baku 8,150.

Sedangkan untuk kemampuan komunikasi matematis, berdasarkan hasil analisis data terhadap rata-rata skor pretes yang dilakukan pada kelompok siswa yang memperoleh pembelajaran melalui model pembelajaran Discovery Learning dengan rata-rata sebesar 4,23 dan pada kelompok siswa yang memperoleh pembelajaran hanya melalui model pembelajaran ceramah dengan rata-rata sebesar 4,44. Dari hasil pengujian data rerata skor pengetahuan pretes terhadap kedua kelompok dapat disimpulkan bahwa kedua kelompok memiliki kemampuan awal yang sama atau tidak terdapat perbedaan yang signifikan. Dengan demikian, disimpulkan pula bahwa kedua kelompok siap untuk menerima materi baru.

\section{SIMPULAN}

Setelah adanya model pembelajaran Discovery Learning untuk kelas eksperimen A dan pembelajaran ceramah untuk kelas eksperimen B, maka diperoleh skor postes untuk kemampuan komunikasi matematik pada kedua kelas. Rerata skor postes kemampuan komunikasi matematik siswa kelas eksperimen adalah 13,38 dan simpangan baku 3,244 demikian pula rerata skor kemampuan komunikasi matematik siswa pada kelas kontrol adalah 7,58 dan simpangan baku 2,487 .

Dari hasil uji rerata menunjukkan bahwa terdapat perbedaan rerata postes kemampuan penalaranmahasiswa kelas eksperimen A dan rerata postes kemampuan penalaran mahasiswa kelas eksperimen B. Berdasarkan uji hipotesis dengan menggunakan analisis ANAVA dua jalur maka diperoleh kemampuan komunikasi matematik mahasiswa dengan $\mathrm{F}$ hitung adalah 104.912 dengan 
signifikansi $\alpha=0,000$. Karena taraf nilai signifikan kemampuan komunikasi lebih kecil dari $\alpha=0,05$, maka dapat disimpulkan bahwa tidak terdapat perbedaan kemampuan komunikasi matematik siswa yang diajarkan dengan model pembelajaran Discovery Learning dan pembelajaran ceramah ditolak sehingga perbedaan kemampuan komunikasi matematik mahasiswa yang diajarkan dengan model pembelajaran Discovery Learning dan pembelajaran ceramah diterima.

\section{DAFTAR RUJUKAN}

Abdurrahman, M. 2009. Pendidikan Bagi Anak Berkesulitan Belajar. Jakarta: PT. Asdi Mahasatya

Departemen Pendidikan Nasional. 2002. Manajemen Peningkatan Mutu Berbasis Sekolah. Jakarta: Direktorat Jenderal Pendidikan Dasar dan Menengah.

Hanafiah Nanang dan Cucu Suhada. 2009. Konsep Strategi Pembelajaran. Bandung: RefikaAditama. Hal: 77

Harijanto, M. 2007. Pengembangan Bahan Ajar untuk Peningkatan Kualitas Pembelajaran Program Pendidikan Pembelajar Sekolah Dasar. Dalam Didaktika, Vol.2 No.1 Hal: 216-226

Iskandar. 2009. Psikologi Pendidikan. Jakarta: Gaung Persada

Lukman dan Ishartiwi. 2014. Pengembangan Bahan Ajar dengan Model mind map untuk Pembelajaran Ilmu Pengetahuan Sosial SMP. Dalam Jurnal
Inovasi Teknologi Pendidikan, Volume 1 - Nomor 2. Hal: 109122.

Majid. 2011. Perencanaan Pembelajaran. Bandung: Rosda. Rajagukguk, W. 2009. Perbedaan Kemampuan Pemecahan Masalah Matematika melalui Pembelajaran Matematika Realistik (PMR) dibandingkan dengan Pembelajaran Konvensional di kelas VII SMP Negeri Medan. Dalam Jurnal Bidang Pendidikan FMIPA UNIMED.

Rajagukguk,W. 2010. Merancang Inovasi Pembelajaran melalui Pengintegrasian Teknologi Informasi dan Komunikasi (ICT) pada Model-Model Pembelajaran Matematika. Makalah disajikan pada seminar Nasional Inovasi Pembelajaran pada tanggal 6 Feb 2010 di UNIMED.

Simanjuntak, E. dkk. 2011. Inovasi Pembelajaran Untuk Meningkatkan Kemampuan Penalaran Matematik Dengan Menggunakan Model Kooperatif Learning Tipe Coop-Coop Pada Mata Kuliah Analisis Real. Prosiding (SEMIRATA BKSPTN wilayah barat bidang MIPA, Medan 2012)

Simanjuntak, E. 2012. Metode Heuristik untuk Menyelesaikan Masalah Optimalisasi Portfolio Berbasis Mean-Variance-Value at Risk. Dalam Jurnal Generasi Kampus Volume 5 Nomor 2 
September 2012, ISSN 1978869X. Hal: 131-147.

Slameto. 2010. Belajar dan Faktor-

Faktor yang Mempengaruhinya.

Jakarta: Rineka Cipta

Suryosubroto B. 2009. Proses

Belajar Mengajar di Sekolah.

Jakarta: Rineka Cipta.

Rieno, dkk. 2013. Pengembangan

Multimedia Pada Pokok

Bahasan Program Linier yang Menggunakan Metode Simpleks.

Dalam Jurnal Pendidikan Matematika dan Sains Tahun I, No. 2. Hal: 108-116.

Riyadi dan Parjon. 2014.

Pengembangan Multimedia

Pembelajaran Matematika

Berbasis Komputer untuk Kelas VIII SMP. Dalam Jurnal Inovasi

Teknologi Pendidikan Volume

1, Nomor 2. Hal: 165-177. 